\title{
Hepatic gene expression involved in glucose and lipid metabolism in transition cows: Effects of fat mobilization during early lactation in relation to milk performance and metabolic changes
}

\author{
C. Weber, ${ }^{*}$ C. Hametner, ${ }^{*}$ A. Tuchscherer, ${ }^{*}$ B. Losand,† E. Kanitz, ${ }^{*}$ W. Otten, ${ }^{*}$ H. Sauerwein,‡ \\ R. M. Bruckmaier,§ F. Becker, ${ }^{*}$ W. Kanitz, ${ }^{*}$ and H. M. Hammon*1 \\ *Leibniz Institute for Farm Animal Biology (FBN), 18196 Dummerstorf, Germany \\ †State Institute of Animal Production, 18196 Dummerstorf, Germany \\ \#Institute of Animal Science, Physiology \& Hygiene Unit, University of Bonn, 53115 Bonn, Germany \\ §Veterinary Physiology, Vetsuisse Faculty, University of Bern, 3001 Bern, Switzerland
}

\begin{abstract}
Insufficient feed intake during early lactation results in elevated body fat mobilization to meet energy demands for milk production. Hepatic energy metabolism is involved by increasing endogenous glucose production and hepatic glucose output for milk synthesis and by adaptation of postcalving fuel oxidation. Given that cows differ in their degree of fat mobilization around parturition, indicated by variable total liver fat concentration (LFC), the study investigated the influence of peripartum fat mobilization on hepatic gene expression involved in gluconeogenesis, fatty acid oxidation, ketogenesis, and cholesterol synthesis, as well as transcriptional factors referring to energy metabolism. German Holstein cows were grouped according to mean total LFC on d 1, 14, and 28 after parturition as low $[<200 \mathrm{mg}$ of total fat/g of dry matter $(\mathrm{DM}) ; \mathrm{n}=10]$, medium (200-300 $\mathrm{mg}$ of total fat/g of DM; $\mathrm{n}=10)$, and high ( $>300 \mathrm{mg}$ of total fat/g of DM; $\mathrm{n}=7$ ), indicating fat mobilization during early lactation. Cows were fed total mixed rations ad libitum and held under equal conditions. Liver biopsies were taken at d 56 and 15 before and d 1, 14, 28, and 49 after parturition to measure mRNA abundances of pyruvate carboxylase $(P C)$; phosphoenolpyruvate carboxykinase; glucose6-phosphatase; propionyl-coenzyme A (CoA) carboxylase $\alpha$; carnitine palmitoyl-transferase $1 \mathrm{~A}$ (CPT1A); acyl-CoA synthetase, long chain 1 (ASCL1); acyl-CoA dehydrogenase, very long chain; 3-hydroxy-3-methylglutaryl-CoA synthase 1 and 2; sterol regulatory elementbinding factor 1; and peroxisome proliferator-activated factor $\alpha$. Total LFC postpartum differed greatly among cows, and the mRNA abundance of most enzymes and transcription factors changed with time during the experimental period. Abundance of $P C$ mRNA increased
\end{abstract}

Received October 17, 2012.

Accepted May 23, 2013.

${ }^{1}$ Corresponding author: hammon@fbn-dummerstorf.de at parturition to a greater extent in high- and mediumLFC groups than in the low-LFC group. Significant $\mathrm{LFC} \times$ time interactions for ACSL1 and CPT1A during the experimental period indicated variable gene expression depending on LFC after parturition. Correlations between hepatic gene expression and performance data and plasma concentrations of metabolites and hormones showed time-specific relations during the transition period. Elevated body fat mobilization during early lactation affected gene expression involved in gluconeogenesis to a greater extent than gene expression involved in lipid metabolism, indicating the dependence of hepatic glucose metabolism on hepatic lipid status and fat mobilization during early lactation.

Key words: dairy cow, fat mobilization, hepatic energy metabolism, gene expression

\section{INTRODUCTION}

The transition from gestation to lactation involves distinctive changes in carbohydrate and lipid metabolism in dairy cows, due to the fact that the energy demand for milk production increases largely after parturition, and nutrient intake during early lactation is not capable to meet energy requirements (Ingvartsen and Andersen, 2000; Drackley et al., 2001). During this time, dairy cows undergo a period of negative energy balance (NEB) that is characterized by the mobilization of body reserves of different tissues, in particular adipose tissue, even when voluntary feed intake increases. In this regard, lipid mobilization in early lactation is considered as noncompromised and varies largely among cows (Ingvartsen et al., 2003). When blood NEFA concentrations increase, NEFA will be taken up by the liver gradually and will be either completely oxidized to carbon dioxide, incompletely oxidized to ketone bodies, or reesterified and stored as triacylglycerides (Herdt, 2000; Drackley et al., 2001; Bobe et al., 2004). Severe NEB linked with excessive fat 
mobilization and fatty liver may lead to metabolic related diseases, such as ketosis and fatty liver disease in dairy cows (Goff and Horst, 1997; Herdt, 2000; Geelen and Wensing, 2006). Prior investigations established huge variations among dairy cows in coping with these metabolic challenges during the transition from pregnancy to lactation. Consequently, some cows are able to adapt very well to new metabolic requirements in early lactation, whereas others do not (Goff and Horst, 1997; Herdt, 2000). The processes of metabolic adaptation depend also on individual cow factors and not only on environmental and management conditions (Jorritsma et al., 2003; Hammon et al., 2009; van Dorland et al., 2009).

The investigation of factors that can predict the metabolic status of dairy cows and the potential susceptibility for periparturient disorders is the focus of many studies and gains on importance in dairy cattle management. We have recently established that liver fat concentration (LFC) after parturition is an indicator for fat mobilization during the transition period and, therefore, a useful marker for the metabolic load in dairy cows during this time (Hammon et al., 2009; Weber et al., 2013). In addition, huge variation was observed among cows with same level of milk production concerning the degree of fat mobilization and the degree of fat mobilization was related to DMI, NEB, and plasma concentrations of glucose, NEFA, and BHBA (Hammon et al., 2009; Weber et al., 2013). These findings suggest different metabolic strategies among cows to support energy demands for milk synthesis during early lactation.

Due to the elevated glucose demand for milk synthesis at the beginning of lactation, the liver increases glucose production, and hepatic glucose output markedly increases to cover glucose demands of the mammary gland (Drackley et al., 2001; Reynolds et al., 2003; Aschenbach et al., 2010). Because of the elevated glucose demands and the insufficient energy intake during early lactation, metabolic and endocrine changes support adaptation of hepatic energy metabolism at the beginning of lactation by stimulating gene expression of transcription factors and enzymes involved in glucose production, FA oxidation, and ketogenesis in the liver (Greenfield et al., 2000; Loor et al., 2005; Loor, 2010). The expression of genes involved in hepatic energy metabolism are affected by diet and nutrient intake (Velez and Donkin, 2005; Loor et al., 2006), but also vary among cows with different metabolic types (Hammon et al., 2010) or variation in postcalving energy mobilization (van Dorland et al., 2009; Hammon et al., 2009). Therefore, changes in LFC, which mirror variations in body fat mobilization and energy metabolism after parturition, may affect hepatic gene expression of key enzymes involved in gluconeogenesis, FA oxidation, and ketogenesis of dairy cows.

The objective of the present study was to determine differences in hepatic gene expression of key enzymes and transcription factors involved in carbohydrate and lipid metabolism in high-yielding dairy cows that vary in fat mobilization during the transition period and to relate time changes of hepatic gene expression data to performance and metabolic data that were published recently (Weber et al., 2013). We hypothesized that gene expression with regard to hepatic carbohydrate and lipid metabolism may be impaired in cows with elevated hepatic fat accumulation. Our findings may contribute to the understanding of hepatic energy metabolism around parturition that relates to differing fat mobilization, which may help to identify strategies for metabolic adaptation of the liver during the transition from pregnancy to lactation.

\section{MATERIALS AND METHODS}

\section{Animals, Husbandry, Feeding, and Milking}

The experimental procedures were carried out according to the animal care guidelines and were approved by the relevant authorities of the State MecklenburgVorpommern, Germany (LALLF M-V TSD 7721.31.1-005/09). German Holstein cows $(\mathrm{n}=27)$, with comparable milk production (second lactation $>10,500$ $\mathrm{kg}$ of milk in $305 \mathrm{~d}$ ), were purchased from 4 local farms after about 300 DIM in second lactation. Cows were studied from wk 8 before parturition to 49 DIM in their third lactation. The drying off period started at wk 8 before expected parturition and cows received dry period therapy (Nafpenzal; Intervet Deutschland GmbH, Unterschleißheim, Germany). Cows were then kept in a freestall barn of the Leibniz Institute for Farm Animal Biology (FBN; Dummerstorf, Germany) to adapt to the new environmental conditions. Housing and feeding management was the same for all cows during the experimental period between wk 8 before parturition and 49 DIM. From d 10 before to d 1 after parturition cows were housed in calving boxes. Cows were clinically healthy and did not suffer from production diseases such as ketosis, fatty liver disease, rumen acidosis, milk fever, or displacement of abomasum, or from infectious diseases.

Diets were provided as TMR ad libitum. The TMR was placed in troughs on scales, which were connected to a computer, and individual feed intake was calculated for each day. Diets were fed at 0700 and $1600 \mathrm{~h}$. Cows received separate dry-off (from wk 8 to 4 before calving), close-up (from wk 3 to calving), and lactation diets according to the recommendations of the German 
Society of Nutrition Physiology (2008) and based on grass and corn silages, as recently published (Weber et al., 2013). Utilizable protein (g/kg of DM), NDF (g/ $\mathrm{kg}$ of $\mathrm{DM})$, and $\mathrm{NE}_{\mathrm{L}}(\mathrm{MJ} / \mathrm{kg}$ of $\mathrm{DM})$ were 127,448 , and 5.8 for the dry-off diet; 133,357 , and 6.4 for the close-up diet; and 164, 299, and 7.1 for the lactation diet, respectively. Details of ingredients and chemical composition of the different diets were recently published in our companion paper (Weber et al., 2013). Dry matter, CP, ADF, NDF, starch, and sugar were determined according to Naumann and Bassler (2004). The cows had free access to water. Cows were milked twice per day.

Based on mean LFC on d 1, 14, and 28 after parturition, cows were classified as low (LO $;<200 \mathrm{mg}$ of total fat/g of DM; $\mathrm{n}=10$ ), medium (MED; 200-300 mg of total fat/g of DM; n = 10), or high $(\mathbf{H I} ;>300 \mathrm{mg}$ of total fat/g of tissue DM; $\mathrm{n}=7$ ) fat-mobilizing groups (Weber et al., 2013). Mean LFC on d 1, 14, and 28 after parturition for HI, MED, and LO were $351 \pm 14,250 \pm$ 10 , and $159 \pm 9 \mathrm{mg} / \mathrm{g}$ of liver tissue DM, respectively. Milk yield was not different among LFC groups during the experimental period ( $\mathrm{LSM} \pm \mathrm{SE}$ was $47.3 \pm 1.3$ $\mathrm{kg} / \mathrm{d}$; Weber et al., 2013).

\section{Blood and Liver Tissue Sampling and Analyses}

Blood samples were taken on d 56 and 15 before expected calving, $1 \mathrm{~d}$ after calving, and on 14, 28, and 49 DIM for determination of plasma concentrations of NEFA, BHBA, glucose, cholesterol, triglycerides, urea, insulin, glucagon, cortisol, leptin, adrenaline, and noradrenaline. Details for blood sampling and respective measurements were published recently in a companion paper (Weber et al., 2013).

Liver biopsy samples were taken by needle biopsy under local anesthesia on d 56 and 15 before parturition and on d 1, 14, 28, and 49 after parturition. After cutting the skin, liver tissue was extracted using a tailor-made biopsy needle (outer diameter $=6 \mathrm{~mm}$ ). Tissue samples (800-1,000 mg by 1 puncture) were immediately frozen in liquid nitrogen and stored at $-80^{\circ} \mathrm{C}$ until analysis. Tissue was homogenized under liquid nitrogen for all analyses. For DM content of the liver, tissue samples were dried at $105^{\circ} \mathrm{C}$ for $3 \mathrm{~h}$. Data for glycogen and fat concentrations in the liver were presented recently (Weber et al., 2013).

Total RNA was isolated from liver samples, transcribed into cDNA, and purified as described by Hammon et al. (2003, 2009). The integrity and purity of RNA were tested by measurement of optical density (ratios at 260 and $280 \mathrm{~nm}$ being greater than 1.9) and by electrophoresis using ethidium bromide staining. Genes associated with carbohydrate metabolism were cytosolic and mitochondrial phosphoenolpyruvate carboxykinase (cytosolic: PCK1; mitochondrial: PCK2), pyruvate carboxylase $(\boldsymbol{P C})$, glucose 6-phosphatase $(\boldsymbol{G} 6 \boldsymbol{P C})$, and propionyl-CoA carboxylase $\alpha(\boldsymbol{P C C A})$. Genes associated with $\beta$-oxidation of FA were carnitine palmitoyl-transferase 1A (CPT1A); acyl-CoA synthetase, long chain (ACSL1); and acyl-CoA dehy-

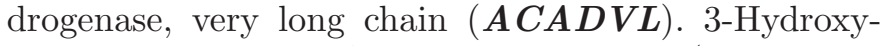
3-methyl-glutaryl-CoA synthase 1 and 2 (HMGCS1 and $\boldsymbol{H M G C S 2 )}$ were genes associated with cholesterol biosynthesis and ketogenesis, respectively. The transcription factors sterol regulatory element-binding factor 1 ( $\boldsymbol{S R E B F 1 )}$ and peroxisome proliferator-

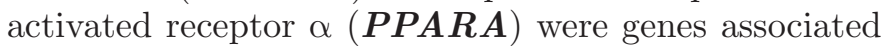
with the regulation of lipid metabolism. Specific primer sequences were used as described in previous studies (Hammon et al., 2009; van Dorland et al., 2009; Graber et al., 2010).

Relative mRNA expression to reference genes in liver tissue was done by real-time reverse-transcription PCR (LightCycler; Roche Applied Science, Mannheim, Germany) using SYBR Green I as fluorescent dye according to Pfaffl (2001). Glyceraldehyde-3-phosphate dehydrogenase $(G A P D H)$ was used as reference gene, because it was not affected by LFC and time. Because $\beta$-actin $(A C T B)$, which was also tested as reference gene, was influenced by time, it was excluded from quantitative analyses. After PCR, temperatures were checked for specificity of each product. Additionally gel electrophoresis of the PCR product demonstrated only a single band of the expected size. Products were verified by sequencing using an ABI Sequencing kit (ABI Big Dye Terminator; Applied Biosystems, Darmstadt, Germany) and an ABI 310 Genetic Analyzer (Applied Biosystems). Values of crossing point (quantification cycle, Cq) were corrected for different runs by an internal standard $(\Delta \mathrm{Cq})$. In addition, $\Delta \mathrm{Cq}_{G A P D H}$ was used to normalize measurements of target genes, as indicated by $\Delta \Delta \mathrm{CP}=\Delta \mathrm{Cq}_{\text {target }}-\Delta \mathrm{Cq}_{\text {GAPDH }}$ (Hammon et al., 2003, 2009). Efficiency of PCR was close to 2 and inter- and intraassay coefficients of variation for reverse-transcription PCR of target and reference genes were $<1 \%$ (Hammon et al., 2003, 2009).

\section{Statistical Analyses}

Statistical analyses were done with the SAS System for Windows, release 9.2 (SAS Institute, 2009). Dry matter and gene expression in liver were assessed by repeated-measurements ANOVA using PROC MIXED using an unstructured type of the block diagonal residual covariance matrix (SAS Institute, 2009). The ANOVA model used contained the fixed effects LFC (HI, MED, and LO), time (day relative to parturition), 
farm (levels: 1, 2, 3, and 4), the interaction LFC $\times$ time, and the covariates milk yield in second lactation, DIM of second lactation, and length of dry period. Nonsignificant covariates were removed in the final model.

For all data, separate analyses were performed for antepartum (d 56 and 15 before parturition), transition (d 15 before parturition, and d 1, 14, and 28 after parturition), postpartum (d 1, 14, 28, and 49 after parturition), and the entire time period of the study (d 56 before parturition to d 49 after parturition). Repeated measures on each animal were taken into account by the repeated statement of PROC MIXED. The least squares means and their standard errors were computed for each fixed effect in the ANOVA model to display the results. Additionally, all LFC differences of these least squares means were tested using the Tukey-Kramer procedure. The CORR procedure (SAS Institute, 2009) was used to calculate and test Pearson correlations by time between data on hepatic gene expression and data generated from measurements of metabolites and hormones in blood plasma and performance data. Test results (ANOVA, Tukey-Kramer, and correlations vs. 0$)$ with $P<0.05$ were considered as significant. Production data and plasma concentrations of metabolites and hormones as well as hepatic glycogen and total LFC were recently published in a companion paper (Weber et al., 2013).

\section{RESULTS}

\section{Hepatic DM and mRNA Expression of Genes in Glucose and Lipid Metabolism}

Dry matter content of liver tissue was similar before parturition in all LCF groups (277 $\pm 4.5 \mathrm{mg} / \mathrm{g}$ of liver tissue), but increased around parturition and postcalving $(P<0.01)$ in all LFC groups, and was lowest in LO $(P<0.01)$ and highest in HI $(P<0.01)$ cows with respect to statistical analysis of the whole experimental period. Hepatic DM content (LSM \pm SEM) for LO, MED, and HI cows during the transition period was $280 \pm 3.8,288 \pm 4.1$, and $315 \pm 49 \mathrm{mg} / \mathrm{g}$ of liver, respectively, and during the postcalving period was $280 \pm 4.6,291 \pm 4.9$, and $317 \pm 5.6 \mathrm{mg} / \mathrm{g}$ of liver, respectively.

Relative mRNA expression of $P C$ was similar for all LFC groups during the dry-off period and increased $(P<0.001)$ at parturition in all LFC groups. With respect to whole time period as well as transition and postpartum period, mRNA abundance of $P C$ was greater $(P<0.05$ or less) in HI than LO cows (Table $1)$. With respect to the transition period, abundance of $P C$ mRNA remained elevated at 14 DIM in HI cows, but decreased to mRNA levels before parturition in
MED and LO cows, resulting in a trend for higher $P C$ mRNA abundance at 14 DIM in HI than in LO cows $(P<0.1)$. In addition, $P C$ mRNA abundance was affected by length of dry period (ANOVA; $P<0.05$ ). The mRNA expression encoding for $P C K 1$ showed a trend for an LFC effect $(P<0.1$; Table 1$)$ and LFC $\times$ time interactions $(P=0.1)$ during the precalving period. Additionally, $P C K 1 \mathrm{mRNA}$ abundance changed with time $(P<0.01)$ when evaluated for the transition, postpartum, and whole experimental period. Lowest PCK1 mRNA abundance was measured on $\mathrm{d} 1$ after parturition, and mRNA abundance increased to 14 DIM in all LFC groups $(P<0.01)$. With respect to transition, postpartum, and whole experimental period, the mRNA expression for $P C K 2$ increased $(P<0.05$ or less) at parturition in all LFC groups and decreased to prenatal levels at 28 DIM (Table 1). Abundance of $P C K 2$ mRNA showed a trend for an LFC effect $(P$ $<0.1)$ during the precalving period and LFC $\times$ time interactions $(P<0.1)$ during the entire period. With respect to transition and whole experimental period, the mRNA abundance for $G 6 P C$ was affected by time $(P<0.01$; Table 1$)$, and increased from d 15 before parturition up to 14 DIM. Trends were observed for LFC $\times$ time interactions during the postcalving $(P=$ $0.1)$ and entire period $(P<0.1)$. Precalving abundance of PCK1 and PCK2 mRNA as well as postcalving abundance of $G 6 P C \mathrm{mRNA}$ were affected by farm. The mRNA expression of $P C C A$ mRNA tended to increase $(P=0.1$; whole experimental period) after parturition, but was not affected by LFC (Table 1 ).

The abundance of ACSL1 mRNA increased $(P<$ 0.01 ; entire study and transition period) at parturition in all LFC groups and the increase was highest $(P<$ $0.05 ;$ LFC $\times$ time interactions during the entire study; Table 1) in HI cows. Postcalving abundance of ACSL1 mRNA was affected by dry period length (ANOVA; $P$ $<0.05)$. The abundance of $C P T 1 A$ mRNA increased $(P<0.01$; entire study and transition period $)$ after parturition in all LFC groups, and the increase was highest in HI cows and lowest in LO cows $(P<0.01$; LFC $\times$ time interactions during the entire study and the transition period; Table 1). The ACADVL mRNA abundance decreased $(P<0.01)$ during the precalving period in all LFC groups, but was not affected by LFC (Table 1).

With regard to the whole experimental period, the mRNA abundance of HMGCS1 increased $(P<0.05)$ from d 56 before parturition to 28 DIM in all LFC groups (Table 1). With respect to all calculated statistical models, ketogenesis-related mRNA abundance of HMGCS2 decreased $(P<0.05)$ during the dry-off period, indicating the lowest mRNA abundance at parturition, and increased $(P<0.05)$ after parturition 
Table 1. Relative mRNA expression $\left(\log _{2}\right)$ of enzymes and nuclear receptors in liver in cows with low (LO), medium (MED), and high (HI) total liver fat concentration (LFC) for fixed time periods: antepartum ( $\mathrm{d}-56$ and -15 ), transition ( $\mathrm{d}-15$ before calving and $\mathrm{d} 1$, 14 , and 28 after calving), postpartum (d 1, 14, 28, and 49), and the entire study (d -56 and -15 before calving, and d 1, 14, 28, and 49 after calving) $)^{1,2}$

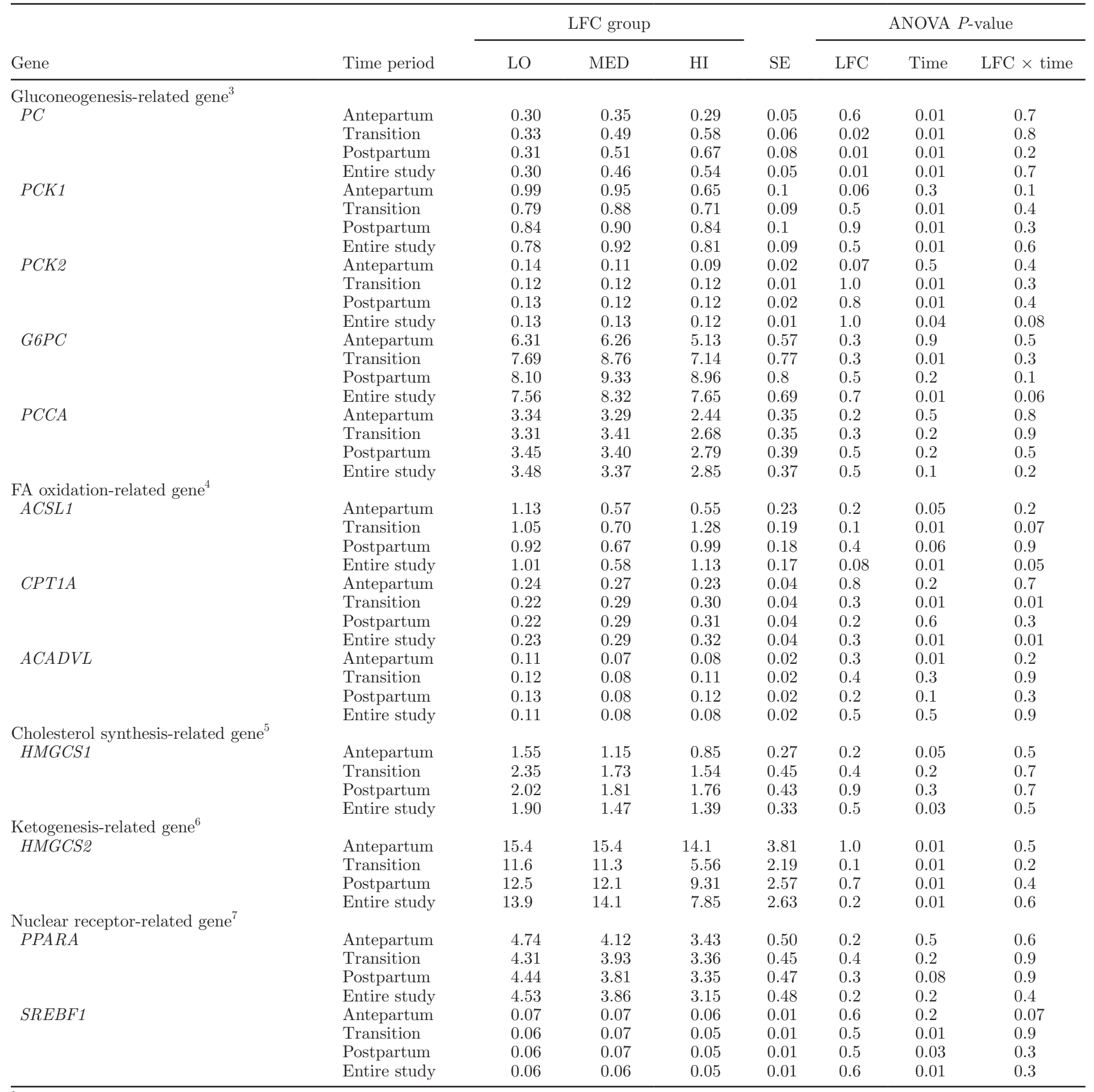

${ }^{1}$ Values are LSM and pooled SEM.

${ }^{2}$ Time courses of parameters are presented as Supplementary Figures S1 to S3 (http://dx.doi.org/10.3168/jds.2012-6277).

${ }^{3} P C=$ pyruvate carboxylase; $P C K 1=$ cytosolic phosphoenolpyruvate carboxykinase; $P C K 2=$ mitochondrial phosphoenolpyruvate carboxykinase; $G 6 P C=$ glucose 6-phosphatase; $P C C A=$ propionyl-CoA carboxylase $\alpha$.

${ }^{4} A C S L 1=$ acyl-CoA synthetase, long chain $1 ; C P T 1 A=$ carnitine palmitoyl-transferase $1 \mathrm{~A} ; A C A D V L=$ acyl-CoA dehydrogenase, very long chain.

${ }^{5} H M G C S 1=3$-hydroxy-3-methyl-glutaryl-CoA synthase 1.

${ }^{6} H M G C S 2=3$-hydroxy-3-methyl-glutaryl-CoA synthase 2.

${ }^{7} P P A R A=$ peroxisome proliferator-activated receptor $\alpha ; S R B E F 1=$ sterol regulatory element-binding factor 1. 
to levels at dry off in all LFC groups. With respect to the transition period, a trend was observed for an LFC effect on HMGCS2 mRNA abundance $(P=0.1$; Table 1). Abundance of HMGCS2 during the entire period was affected $(P<0.05)$ by milk yield in second lactation, indicating greater HMGCS2 mRNA abundance with greater milk yield in the second lactation. With respect to postpartum statistical calculation, a trend $(P=0.1)$ was observed for a time effect on mRNA expression of PPARA, but PPARA was not affected by LFC (Table 1). Abundance of SREBF1 mRNA was affected by time $(P<0.05$ or less; entire study and transition and postcalving periods) and increased before parturition in MED and $\mathrm{HI}$ cows, but decreased in LO cows (interaction LCF $\times$ time: $P<0.1$; Table 1 ), and decreased at parturition, but increased thereafter in all LFC groups.

\section{Correlations Between mRNA Abundance of Hepatic Genes and Zootechnical Data and Plasma Metabolites and Hormones As Well As Hepatic Glycogen and Fat}

Significant correlations between mRNA abundance and performance data, plasma metabolites and hormones, as well as LFC and hepatic glycogen concentrations are shown in Figure 1, considering all 27 cows that were investigated in this study. Performance data, plasma concentrations of metabolites and hormones, and LFC and glycogen concentrations in the liver were recently presented in a companion paper (Weber et al., 2013). The pattern of correlations (solid lines for positive, and dashed lines for negative correlations) changed among different time points. Details on respective correlations are shown in Supplementary Tables S1 to S6 (http://dx.doi.org/10.3168/jds.2012-6277).

On $\mathrm{d}-56, A C A D V L$ and $A C S L 1$ were positively correlated with plasma concentrations of NEFA, BHBA, and cortisol, but CPT1A was negatively associated with hepatic glycogen concentration. Concentrations of $P C K 1, P C K 2$, and $G 6 P C$ mRNA were negatively correlated with plasma noradrenaline. Plasma cholesterol concentrations were positively correlated with $P C C A$, G6PC, CPT1A, PPARA, SREBF1, but not with $H M G C S 1$ (Figure 1A).

On d $-15, P C$ was positively correlated with the glucagon:insulin ratio in plasma, but $P C$ and $P C K 1$ were negatively correlated with plasma BHBA concentrations. A trend for a negative correlation was also observed between $P C$ and DMI $(\mathrm{r}=-0.38 ; P<0.1)$. Sterol regulatory element-binding factor 1 was positively correlated with plasma concentrations of cortisol and leptin, but was negatively correlated with glycogen concentration in liver (Figure 1B).
On d 1, PC was positively correlated with plasma cortisol, but was negatively correlated with DMI. Plasma glucagon concentrations were negatively correlated with PCCA, CPT1, PPARA, and SREBF1, but plasma insulin concentrations were positively correlated with PCK1, PCK2, and ACSL1. In addition, PCK2 was negatively correlated with adrenaline, whereas $P C K 1$ was negatively correlated with NEFA and noradrenaline. Hepatic glycogen concentration was negatively correlated with CPT1A and G6PC, and SREBF1 was positively correlated with plasma cortisol; $A C A D V L$ was positively correlated with NEFA (Figure 1C).

On d $14, P C$ was positively correlated with plasma concentrations of NEFA and BHBA, but was negatively correlated with plasma glucose and hepatic glycogen concentrations. Dry matter intake was positively correlated with $P C C A, A C A D V L, H M G C S 2$, and PPARA, and tended to be positively correlated with $P C K 1(\mathrm{r}=$ $0.36 ; P<0.1)$ and $P C K 2(\mathrm{r}=0.38 ; P<0.1)$. Energy balance was positively correlated with $P P A R A ; C P T 1 A$ was positively correlated with LFC. Acetone concentrations in milk were negatively correlated with $P C C A$ and $G 6 P C$, and several hepatic parameters were positively correlated with milk protein and lactose concentrations (Figure 1D).

On d 28, ECM was positively correlated with $P C K 1$ and $P C K 2$, and $P C K 1$ was positively correlated with milk fat concentration, but negatively with energy balance, whereas $P C K 2$ was positively correlated with plasma concentrations of BHBA. Pyruvate carboxylase mRNA was negatively correlated with DMI and hepatic glycogen concentrations. Plasma adrenaline concentrations were positively correlated with $P C C A, C P T 1 A$, $H M G C S 1$, and $S R E B F 1$, whereas plasma glucagon concentrations were negatively correlated with $G 6 P C$, $P C C A$, and CPT1A. Plasma insulin concentrations were negatively correlated with $A C A D V L$ (Figure $1 \mathrm{E}$ ).

On d $49, P C$ was positively correlated with fat:protein ratio in milk and BHBA, but negatively with milk protein concentration, energy balance, and hepatic glycogen concentrations. Hepatic glycogen concentrations were also negatively correlated with $P C K 1$, but positively with PPARA and SREBF1. Cytosolic phosphoenolpyruvate carboxykinase was positively correlated with plasma NEFA concentrations. Energy-corrected milk and LFC were positively correlated with CPT1A, but LFC were negatively correlated with $A C A D V L$ and PPARA (Figure 1F).

\section{DISCUSSION}

Cows investigated in this study markedly differed in their energy metabolism during the transition from pregnancy to lactation, indicated by highly variable fat 
A

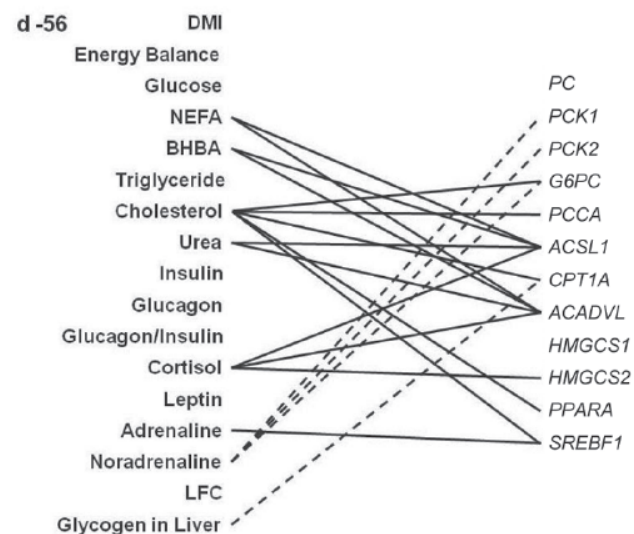

C

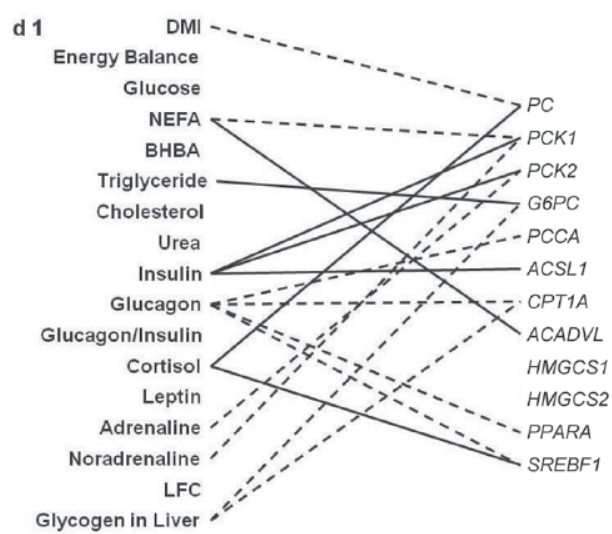

E

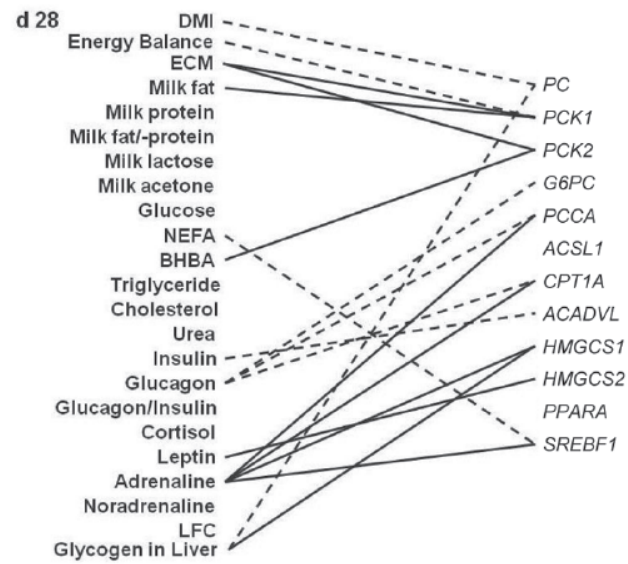

$B$

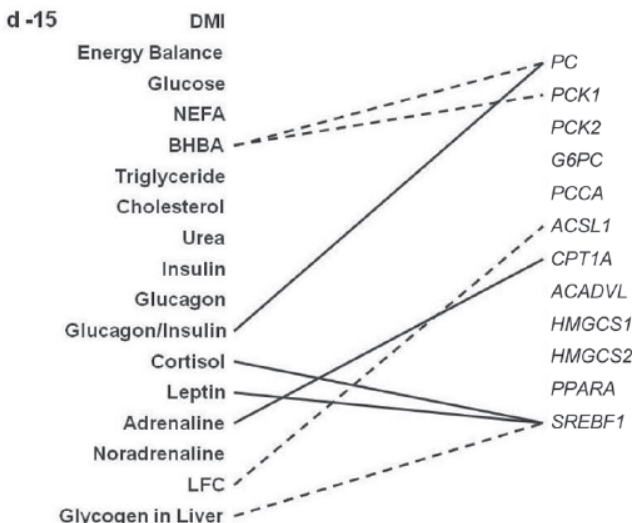

D

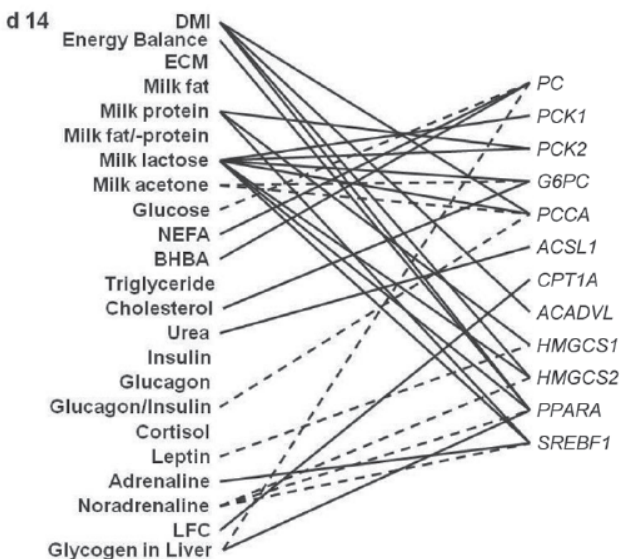

F

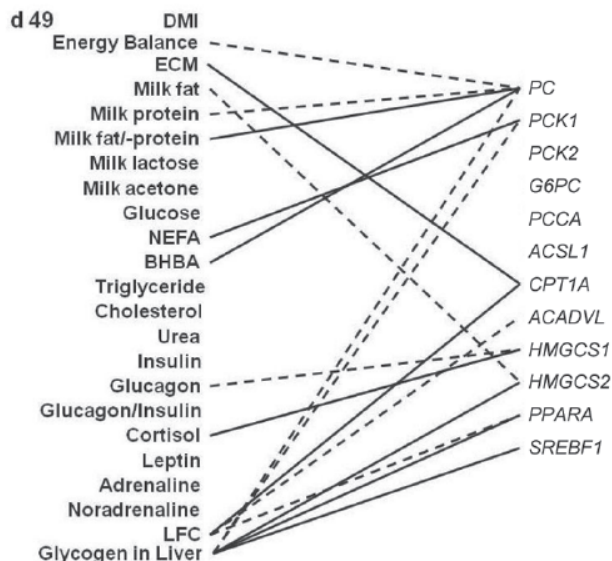

Figure 1. Correlations (Pearson correlation) of mRNA abundance of hepatic factors involved in energy metabolism and parameters related to performance and systemic energy metabolism on d -56 (A), -15 (B), 1 (C), 14 (D), 28 (E) and 49 (F) relative to parturition. Only correlations are shown with $P<0.05$. Solid lines represent positive and dashed lines represent negative correlations. Details on correlation coefficients and $P$-values are presented in Supplementary Tables S1-S6 (http://dx.doi.org/10.3168/jds.2012-6277). LFC = liver fat concentration; $P C=$ pyruvate carboxylase; $P C K 1=$ cytosolic phosphoenolpyruvate carboxykinase; $P C K 2=$ mitochondrial phosphoenolpyruvate carboxykinase; $G 6 P C=$ glucose 6 -phosphatase; $P C C A=$ propionyl-CoA carboxylase $\alpha ; A C S L 1=$ acyl-CoA synthetase, long chain $1 ; C P T 1 A=$ carnitine palmitoyl-transferase 1A; $A C A D V L=$ acyl-CoA dehydrogenase, very long chain; HMGCS1 = 3-hydroxy-3-methyl-glutaryl-CoA synthase 1; $H M G C S 2=3$-hydroxy-3-methyl-glutaryl-CoA synthase 2; PPARA = peroxisome proliferator-activated receptor $\alpha ; S R E B F 1=$ sterol regulatory element-binding factor 1 . 
mobilization and LFC. We have investigated pre- and postcalving changes of key hepatic factors involved in gluconeogenesis, $\beta$-oxidation, ketogenesis, and cholesterol synthesis, as well as regulatory nuclear factors. Correlations performed in this study focused on the relationship between production data as well as plasma concentrations of metabolites and hormones with gene expression data of hepatic factors at same time points. We intended to investigate the influence of extra-hepatic parameters (and hepatic glycogen concentration and LFC) on hepatic gene expression related to energy metabolism. Correlations within gene expression of hepatic enzymes were not performed to avoid an overwhelming number of relationships among hepatic enzymes and regulatory factors that were recently shown (van Dorland et al., 2009; Loor, 2010).

\section{Associations of Metabolites and Hormones and Effects of Fat Mobilization on Gene Expression of Hepatic Enzymes Involved in Gluconeogenesis}

Pyruvate carboxylase, phosphoenolpyruvate carboxykinase, propionyl-CoA carboxylase, and glucose 6-phosphatase play crucial roles in bovine hepatic gluconeogenesis to ensure a high glucose output during early lactation for milk synthesis (Baird et al., 1968; Donkin, 1999; Aschenbach et al., 2010). Hepatic gene expression of most of these enzymes increased during the transition from pregnancy to lactation, but time changes differed among enzymes. Gene expression of $P C, P C K 2$, and $G 6 P C$ increased immediately at parturition, whereas $P C K 1$ mRNA increased 2 wk after parturition and time changes of $P C C A$ mRNA after parturition were weak. Comparable time patterns were described in previous studies (Greenfield et al., 2000; Hammon et al., 2009; van Dorland et al., 2009), indicating different regulation of genes involved in gluconeogenesis with the onset of lactation. Due to insufficient feed intake at parturition, a shift occurs in substrate availability for hepatic gluconeogenesis [i.e., fractional lactate, amino acids (especially alanine)], and glycerol utilization increases, but fractional propionate utilization for gluconeogenesis decreases (Lomax and Baird, 1983; Reynolds et al., 2003; Aschenbach et al., 2010). These changes in substrate availability might favor gene expression of $P C$ and $P C K 2$ instead of $P C K 1$ (Brockman, 2005). Interestingly, $P C$, but not $P C K 1$, mRNA abundance increased during feed restriction in dairy cows (Velez and Donkin, 2005), indicating comparable mRNA expression patterns of $P C$ during the early transition period and feed restriction.

The increased $P C$ mRNA coincides with the time point of maximal reduced feed intake (Greenfield et al., 2000; Loor et al., 2006). We have found a negative association between hepatic $P C$ mRNA abundance and DMI at parturition, but also at $\mathrm{d}-15(P<0.1)$ and 28 . At parturition, $P C$ mRNA abundance increased much more in HI and MED cows than in LO cows. Recent findings in the liver of dairy cows indicated elevated hepatic PC concentrations on protein expression of PC when LFC was elevated after parturition (Sejersen et al., 2012). At the same time, DMI was lower in cows with elevated LFC (Hammon et al., 2009; Sejersen et al., 2012; Weber et al., 2013). Dry matter intake has a significant effect on hepatic $P C$ gene expression at parturition. Reduced DMI is associated with elevated plasma NEFA concentrations around parturition in dairy cows (Ingvartsen and Andersen, 2000; Drackley et al., 2001; Hammon et al., 2009) and NEFA may stimulate hepatic $P C$ gene expression by activating $P C$ promoter 1 (White et al., 2011). Indeed, a positive association was observed between $P C$ mRNA abundance and plasma NEFA concentrations at 14 DIM. Interestingly, the increase in $P C$ mRNA abundance at parturition was greater when cows had reduced energy intake before parturition (Loor et al., 2006), which supports findings in HI cows.

The delayed increase in PCK1 mRNA abundance after parturition supports previous findings (Greenfield et al., 2000; Karcher et al., 2007; Hammon et al., 2009) and, as mentioned above, is different from the increase in PCK2 mRNA abundance at parturition, as seen previously (van Dorland et al., 2009). Time changes in $P C K 2$ gene expression around parturition were shown in some (van Dorland et al., 2009; Graber et al., 2010), but not in all studies (Agca et al., 2002; Hammon et al., 2009). Because lactate is the preferred precursor when phosphoenolpyruvate is synthesized from oxaloacetate by mitochondrial phosphoenolpyruvate carboxykinase (Hanson and Reshef, 1997; Aschenbach et al., 2010), our findings support the importance of lactate as substrate for gluconeogenesis after parturition in dairy cows, when propionate availability is low (Reynolds et al., 2003; Doepel et al., 2009; Aschenbach et al., 2010). The decelerated increase in PCK1 mRNA may reflect the postnatal increase in DMI and the elevated use of propionate as substrate for gluconeogenesis, as discussed in previous studies (Greenfield et al., 2000; Reynolds et al., 2003; Hammon et al., 2009). Time changes relative to parturition were also described for G6PC (Cedeño et al., 2008; Graber et al., 2010). In our study, the time course of hepatic G6PC mRNA abundance differed from other gluconeogenic enzymes, as the increase started at the same time as seen for $P C$ and $P C K 2$ mRNA, and was still elevated up to 49 DIM, as seen for PCK1 mRNA. Surprisingly, only weak time changes were seen for $P C C A$ mRNA abundance. In our study, differences in DMI were obviously not 
high enough to affect mRNA abundance, which was especially expected for $P C C A$ due to differences in propionate availability with respect to changes in DMI (Bergman, 1990; Aschenbach et al., 2010).

Gene expression of PCK1, PCK2, G6PC, and PCCA was not affected by LFC, indicating that hepatic fat content and body fat mobilization did not influence gene expression of these enzymes. However, elevated LFC depressed phosphoenolpyruvate carboxykinase enzyme activities in cows with induced fatty liver around parturition (Rukkwamsuk et al., 1999). Although Murondoti et al. (2004) described impaired activities of gluconeogenic enzymes in liver with elevated fat content, changes in enzymatic activities in the liver of ketotic cows with elevated LFC were surprisingly low (Baird et al., 1968) and gene expression of enzymes involved in gluconeogenesis was not depressed in a recent study (Hammon et al., 2009) and in the present study.

Regulation of hepatic gene expression of gluconeogenic enzymes is under substrate and endocrine control and differs from that of monogastric animals (McDowell, 1983; Brockman and Laarveld, 1986; Aschenbach et al., 2010). However, the number of correlations of metabolites and hormones with mRNA abundance of gluconeogenic enzymes changed with time and was generally lower during the transition from pregnancy to lactation. Abundance of $P C$ mRNA was positively associated with the glucagon:insulin ratio in plasma only on d -15 and with plasma cortisol concentrations only on $\mathrm{d} 1$. Both associations may have contributed to stimulation of hepatic $P C$ mRNA abundance (Jitrapakdee and Wallace, 1999). Except for the negative relation between $P C$ mRNA and plasma glucose on d 14, glucose had less effect on mRNA abundance of gluconeogenic enzymes in our study. In support of our findings, plasma glucose concentrations were not associated with protein concentrations of gluconeogenic enzymes in the liver of dairy cows (Sejersen et al., 2012). Changes in the glucose and insulin status in dairy cows by glucose or insulin treatment, or both, indicated only minor changes in gene expression of gluconeogenic enzymes, implying less regulation of gene expression of gluconeogenic enzymes by the glucose and insulin status in dairy cows around parturition (Al-Trad et al., 2010; Kreipe et al., 2011). On the other hand, a negative relationship was observed between hepatic glycogen concentration and particularly $P C$ mRNA abundance during lactation, pointing at a feedback mechanism of stored hepatic glycogen on gluconeogenesis.

Overall, changes in gene expression after parturition and with regard to elevated LFC did not indicate impaired gluconeogenesis in the current study, which supports recent data (Hammon et al., 2009; Sejersen et al., 2012), but gene expression responds to the metabolic status of the liver with distinct changes in gluconeogenic enzymes.

\section{Associations of Metabolites and Hormones and Effects of Fat Mobilization on Gene Expression of Hepatic Enzymes Involved in FA Oxidation, Ketogenesis, and Cholesterol Synthesis and Their Regulation}

Long-chain FA must be activated by ACSL-1, before they can be transported into the mitochondria via CPT1A, and a trans- $\alpha \beta$ double bond can be formed by ACADVL to start mitochondrial $\beta$-oxidation (Voet and Voet, 1995). In our study, the mRNA abundance of ACSL1, CPT1A, and ACADVL increased in all LFC groups after parturition, which is in agreement with previous studies (Loor et al., 2005; van Dorland et al., 2009; Graber et al., 2010). Overall, our data on gene expression of enzymes involved in $\beta$-oxidation pointed at postcalving stimulation of hepatic FA oxidation to cover energy demands in the liver, especially for gluconeogenesis (Loor, 2010). Elevated CPT1 activities (Mizutani et al., 1999; Dann and Drackley, 2005) and a greater protein expression of ACSL-1 (Sejersen et al., 2012) in the liver were seen in cows with elevated LFC. However, because differences in gene expression of enzymes involved in hepatic $\beta$-oxidation were weak with respect to LFC classification in our study, we concluded that cows with variable LFC may not suffer from impaired hepatic FA oxidation.

Correlations of LFC with enzymes involved in hepatic $\beta$-oxidation did not behave in a consistent manner (i.e., LFC was positively associated with CPT1A on d 14 and 49 , but was negatively associated with ACSL1 on d 1 and $A C A D V L$ on d 28). Correlations of genes involved in hepatic $\beta$-oxidation with metabolites and hormones changed with time, and the number of correlations was highest on $\mathrm{d}-56$, when positive associations between mRNA abundance of ACSL1 and ACADVL and plasma concentrations of NEFA, BHBA, as well as plasma cortisol were seen. With one exception on d 1, these correlations disappeared around parturition and during early lactation. On the other hand, plasma adrenaline concentrations were positively correlated with CPT1A mRNA abundance on d -15 and 28, respectively, supposing some endocrine regulation of factors involved in $\beta$-oxidation, but not around parturition.

Hepatic gene expression of HMGCS2, which is involved in ketogenesis (Voet and Voet, 1995), changed over time and did not comply with plasma concentrations of BHBA before parturition, but both plasma BHBA and hepatic HMGCS2 mRNA increased with the onset of lactation (Weber et al., 2013). Time changes of hepatic HMGCS2 mRNA during transition 
from pregnancy to lactation were as described recently (van Dorland et al., 2009). The huge increase of plasma BHBA concentrations in blood and acetone concentrations in milk after parturition in HI cows (Weber et al., 2013) was not reflected by changes in hepatic HMGCS2 gene expression. Furthermore, HMGCS2 gene expression did not correlate with BHBA in blood plasma and acetone in milk at single time points during lactation. The absence of such correlations was also seen by van Dorland et al. (2009). Interestingly, hepatic HMGCS2 gene and protein expression were reduced in ketotic dairy cows, indicating a negative feedback mechanism due to BHBA plasma concentrations (Li et al., 2012).

Gene expression of HMGCS1 increased around parturition, whereas plasma concentrations of cholesterol strongly decreased at parturition in all LFC groups (Weber et al., 2013). The cytosolic form of HMGCS is involved in cholesterol synthesis in the liver, besides 3-hydroxy-3-methyl-glutaryl-CoA reductase, mevalonate kinase, and farnesyl diphosphate synthase, which all increased in dairy cows at parturition (Viturro et al., 2009; Schlegel et al., 2012). No significant correlations were found between plasma cholesterol and hepatic HMGCS1 mRNA in our study, as also indicated by van Dorland et al. (2009). Therefore, our study does not allow us to conclude an impaired hepatic cholesterol synthesis in cows with elevated LFC, but other factors such as onset of milk production may have contributed to increased hepatic gene expression of HMGCS1 ( Viturro et al., 2009).

Nuclear receptors such as PPARA and SREBF1 are ligand-activated transcription factors that are involved in lipid metabolism around parturition in dairy cows, either stimulating $\beta$-oxidation and ketogenesis with NEFA as ligand (PPARA) or lipogenesis (SREBF1; Desvergne et al., 2006; Loor, 2010). Gene expression of PPARA in our study hardly changed with time. Absence of time effects was mentioned previously (van Dorland et al., 2009), but several studies indicated elevated gene expression of PPARA after parturition and with increased plasma concentrations of NEFA (Loor et al., 2005; Graber et al., 2010). The decrease in SREBF1 mRNA abundance at d 1 in all LFC groups mirrored the reduced lipogenic activities in the liver of dairy cows around parturition and is supported by previous studies (Loor et al., 2005; Duske et al., 2009; Graber et al., 2010).

\section{Overall Relations of Extra-Hepatic Parameters to Hepatic Factors Involved in Energy Metabolism During the Transition Period}

Milk parameters such as milk protein and lactose and DMI showed the strongest relationship to hepatic fac- tors, particularly at 14 DIM when energy balance was lowest for all cows due to insufficient DMI (Weber et al., 2013). The large number of correlations between milk ingredients and hepatic factors pointed at the high nutrient priority of the mammary gland for milk synthesis that is well known in lactating cows (Goff and Horst, 1997; Bauman, 2000; Drackley et al., 2001). In addition, the great number of positive correlations between DMI and hepatic factors at 14 DIM indicated the importance of nutrient supply for sustaining hepatic function on energy metabolism (Ingvartsen and Andersen, 2000; Drackley et al., 2001).

On the other hand, numbers of correlations between hormones and hepatic factors in general were low. At dry off, most correlations were seen for cortisol and noradrenaline, at parturition for glucagon and insulin, at 14 DIM for noradrenaline, and at 28 DIM for adrenaline. In part, associations between hormones and hepatic factors were contrary to that which is known from text books (Brockman and Laarveld, 1986; Donkin, 1999; e.g., the negative correlations of noradrenaline with mRNA abundance of gluconeogenic enzymes at $d-56$ and at parturition and the positive correlations of insulin with gluconeogenic enzyme expression at parturition). Obviously, these correlations represent negativefeedback mechanisms, but further investigations are necessary to explain their relationships. Interestingly, correlations of liver glycogen concentrations with gene expression of factors involved in energy metabolism increased with time postpartum, which may point at direct substrate regulation due to the improved energy status with ongoing lactation.

\section{CONCLUSIONS}

Cows differing in body fat mobilization around parturition indicated clear differences in postcalving hepatic $P C$ gene expression, whereas gene expression involved in hepatic fat metabolism and transcription factors related to fat metabolism were less affected. Low LFC in LO cows was linked to fewer changes, especially in hepatic $P C$ mRNA, during the transition period; thus, LO cows may require less hepatic adaptation during the transition period than HI and MED cows with respect to hepatic carbohydrate metabolism. Differences in LFC among cows were probably not the result of impaired FA oxidation in liver, because differences in gene expression related to $\beta$-oxidation were weak, but were not impaired with respect to LFC. Our study pointed out a distinct effect on adaptation of hepatic glucose metabolism, but fewer changes in FA oxidation in cows with variable fat mobilization during the transition from pregnancy to lactation. 


\section{ACKNOWLEDGMENTS}

The authors gratefully acknowledge the laboratory staff (Claudia Reiko, Anne-Kathrin Möller, Brigitte Waischnow, and Susanne Dwars) and animal care takers (Dirk Oswald, Roland Gaeth, Astrid Schulz, and Kerstin Korinth) of the Research Unit Nutritional Physiology, Leibniz Institute for Farm Animal Biology (FBN; Dummerstorf, Germany), as well as Bernd Stabenow and the Animal Experimental Unit of the FBN for excellent technical assistance. We thank the Cattle Breeding Union Mecklenburg-Vorpommern (RMV; Germany) for supporting us in dairy cow selection for this study. The study was supported by the Federal Ministry of Education and Research (BMBF; FUGATOplus project, REMEDY), Germany.

\section{REFERENCES}

Agca, C., R. B. Greenfield, J. R. Hartwell, and S. S. Donkin. 2002. Cloning and characterization of bovine cytosolic and mitochondrial PEPCK during transition to lactation. Physiol. Genomics 11:53-63.

Al-Trad, B., T. Wittek, G. B. Penner, K. Reisberg, G. Gäbel, M. Fürll, and J. R. Aschenbach. 2010. Expression and activity of key hepatic gluconeogenesis enzymes in response to increasing intravenous infusions of glucose in dairy cows. J. Anim. Sci. 88:2998-3008.

Aschenbach, J. R., N. B. Kristensen, S. S. Donkin, H. M. Hammon, and G. B. Penner. 2010. Gluconeogenesis in dairy cows: The secret of making sweet milk from sour dough. IUBMB Life $62: 869-877$.

Baird, G. D., K. G. Hibbitt, G. D. Hunter, P. Lund, M. Stubbs, and H. A. Krebs. 1968. Biochemical aspects of bovine ketosis. Biochem. J. $107: 683-689$.

Bauman, D. E. 2000. Regulation of nutrient partitioning during lactation: Homeostasis and homeorhesis revisited. Pages 311-328 in Ruminant Physiology: Digestion, Metabolism, Growth and Reproduction. P. B. Cronjé, ed. CAB International, Wallingford, UK.

Bergman, E. N. 1990. Energy contributions of volatile fatty acids from the gastrointestinal tract in various species. Physiol. Rev. 70:567-590.

Bobe, G., J. W. Young, and D. C. Beitz. 2004. Invited review: Pathology, etiology, prevention, and treatment of fatty liver in dairy cows. J. Dairy Sci. 87:3105-3124.

Brockman, R. P. 2005. Glucose and short-chain fatty acid metabolism. Pages 291-310 in Quantitative Aspects of Ruminant Digestion and Metabolism. J. Dijkstra, J. M. Forbes, and J. France, ed. CAB International, Oxfordshire, UK.

Brockman, R. P., and B. Laarveld. 1986. Hormonal regulation of metabolism in ruminants; a review. Livest. Prod. Sci. 14:313-334.

Cedeño, E. M., S. L. Koser, and S. S. Donkin. 2008. Quantification of glucose-6-phosphatase mRNA abundance in liver of transition dairy cows. J. Dairy Sci. 91(Suppl. 1):424 (Abstr.)

Dann, H. M., and J. K. Drackley. 2005. Carnitine palmitoyltransferase I in liver of periparturient dairy cows: effects of prepartum intake, postpartum induction of ketosis, and periparturient disorders. J. Dairy Sci. 88:3851-3859.

Desvergne, B., L. Michalik, and W. Wahli. 2006. Transcriptional regulation of metabolism. Physiol. Rev. 86:465-514.

Doepel, L., G. E. Lobley, J. F. Bernier, P. Dubreuil, and H. Lapierre. 2009. Differences in splanchnic metabolism between late gestation and early lactation dairy cows. J. Dairy Sci. 92:3233-3243.

Donkin, S. S. 1999. Role of the endocrine pancreas in animal metabolism, growth and performance. Pages 315-328 in Biology of the Pancreas in Growing Animals. S. G. Pierzynowski and R. Zabielski, ed. Elsevier, Amsterdam, the Netherlands.
Drackley, J. K., T. R. Overton, and G. N. Douglas. 2001. Adaptations of glucose and long-chain fatty acid metabolism in liver of dairy cows during the periparturient period. J. Dairy Sci. 84(E. Suppl.):E100-E112.

Duske, K., H. M. Hammon, A.-K. Langhof, O. Bellmann, B. Losand, K. Nürnberg, G. Nürnberg, H. Sauerwein, H. M. Seyfert, and C. C. Metges. 2009. Metabolism and lactation performance in dairy cows fed a diet containing rumen-protected fat during the last twelve weeks of gestation. J. Dairy Sci. 92:1670-1684.

Geelen, M. J. H., and T. Wensing. 2006. Studies on hepatic lipidosis and coinciding health and fertility problems of high-producing dairy cows using the "Utrecht fatty liver model of dairy cows". A review. Vet. Q. 28:90-104.

German Society of Nutrition Physiology. 2008. Ausschuss für Bedarfsnormen der Gesellschaft für Ernährungsphysiologie, No. 9. Empfehlungen zur Energie- und Nährstoffversorgung der Milchkühe und Aufzuchtrinder (Recommended energy and nutrient supply for dairy cows and growing cattle). DLG Verlag, Frankfurt am Main, Germany.

Goff, J. P., and R. L. Horst. 1997. Physiological changes at parturition and their relationship to metabolic disorders. J. Dairy Sci. 80:1260-1268.

Graber, M., S. Kohler, T. Kaufmann, M. G. Doherr, R. M. Bruckmaier, and H. A. van Dorland. 2010. A field study on characteristics and diversity of gene expression in the liver of dairy cows during the transition period. J. Dairy Sci. 93:5200-5215.

Greenfield, R. B., M. J. Cecava, and S. S. Donkin. 2000. Changes in mRNA expression for gluconeogenic enzymes in liver of dairy cattle during the transition to lactation. J. Dairy Sci. 83:1228-1236.

Hammon, H. M., C. C. Metges, A. Schulz, P. Junghans, J. Steinhoff, F. Schneider, R. Pfuhl, R. M. Bruckmaier, R. Weikard, and C. Kühn. 2010. Differences in milk production, glucose metabolism, and carcass composition of two Charolais $\times$ Holstein $\mathrm{F}_{2}$ families derived from reciprocal paternal and maternal grandsire crosses. J. Dairy Sci. 93:3007-3018.

Hammon, H. M., S. N. Sauter, M. Reist, Y. Zbinden, C. Philipona, C. Morel, and J. W. Blum. 2003. Dexamethasone and colostrum feeding affect hepatic gluconeogenic enzymes differently in neonatal calves. J. Anim. Sci. 81:3095-3106.

Hammon, H. M., G. Stürmer, F. Schneider, A. Tuchscherer, H. Blum, T. Engelhard, A. Genzel, R. Staufenbiel, and W. Kanitz. 2009. Performance and metabolic and endocrine changes with emphasis on glucose metabolism in high-yielding dairy cows with high and low fat content in liver after calving. J. Dairy Sci. 92:1554-1566.

Hanson, R. W., and L. Reshef. 1997. Regulation of phosphoenolpyruvate carboxykinase $(G T P)$ gene expression. Annu. Rev. Biochem. 66:581-611.

Herdt, T. H. 2000. Ruminant adaptation to negative energy balance. Influences on the etiology of ketosis and fatty liver. Vet. Clin. North Am. Food Anim. Pract. 16:215-230.

Ingvartsen, K. L., and J. B. Andersen. 2000. Integration of metabolism and intake regulation: A review focusing on periparturient animals. J. Dairy Sci. 83:1573-1597.

Ingvartsen, K. L., R. J. Dewhurst, and N. C. Friggens. 2003. On the relationship between lactational performance and health: Is it yield or metabolic imbalance that cause production diseases in dairy cattle? A position paper. Livest. Prod. Sci. 83:277-308.

Jitrapakdee, S., and J. C. Wallace. 1999. Structure, function and regulation of pyruvate carboxylase. Biochem. J. 340:1-16.

Jorritsma, R., T. Wensing, T. A. M. Kruip, P. L. A. M. Vos, and J. P. T. M. Noordhuizen. 2003. Metabolic changes in early lactation and impaired reproductive performance in dairy cows. Vet. Res. 34:11-26.

Karcher, E. L., M. M. Pickett, G. A. Varga, and S. S. Donkin. 2007. Effect of dietary carbohydrate and monensin in expression of gluconeogenic enzymes in the liver of transition dairy cows. J. Anim. Sci. 85:690-699.

Kreipe, L., M. C. M. B. Vernay, A. Oppliger, O. Wellnitz, R. M. Bruckmaier, and H. A. van Dorland. 2011. Induced hypoglycemia for 48 hours indicates differential glucose and insulin effects on liver metabolism in dairy cows. J. Dairy Sci. 94:5435-5448. 
Li, P., X. B. Li, S. X. Fu, C. C. Wu, X. X. Wang, G. J. Yu, M. Long, Z. Wang, and G. W. Liu. 2012. Alterations of fatty acid $\beta$-oxidation capability in the liver of ketotic cows. J. Dairy Sci. 95:1759-1766.

Lomax, M. A., and G. D. Baird. 1983. Blood flow and nutrient exchange across the liver and gut of the dairy cow. Effects of lactation and fasting. Br. J. Nutr. 49:481-496.

Loor, J. J. 2010. Genomics of metabolic adaptations in the peripartal cow. Animal 4:1110-1139.

Loor, J. J., H. M. Dann, R. E. Everts, R. Oliveira, C. A. Green, N. A. J. Guretzky, S. L. Rodriguez-Zas, H. A. Lewin, and J. K. Drackley. 2005. Temporal gene expression profiling of liver from periparturient dairy cows reveals complex adaptive mechanisms in hepatic function. Physiol. Genomics 23:217-226.

Loor, J. J., H. M. Dann, N. A. J. Guretzky, R. E. Everts, R. Oliveira, C. A. Green, N. B. Litherland, S. L. Rodriguez-Zas, H. A. Lewin, and J. K. Drackley. 2006. Plane of nutrition prepartum alters hepatic gene expression and function in dairy cows as assessed by longitudinal transcript and metabolic profiling. Physiol. Genomics $27: 29-41$.

McDowell, G. H. 1983. Hormonal control of glucose homoeostasis in ruminants. Proc. Nutr. Soc. 42:149-167.

Mizutani, H., T. Sako, Y. Toyoda, T. Kawabata, N. Urumuhang, H. Koyama, and S. Motoyoshi. 1999. Preliminary studies on hepatic carnitine palmitoyltransferase in dairy cattle with or without fatty liver. Vet. Res. Commun. 23:475-480.

Murondoti, A., R. Jorritsma, A. C. Beynen, T. Wensing, and M. J. H. Geelen. 2004. Activities of the enzymes of hepatic gluconeogenesis in periparturient dairy cows with induced fatty liver. J. Dairy Res. 71:129-134.

Naumann, C., and R. Bassler. 2004. Die chemische Untersuchung von Futtermitteln. 3rd ed. VDLUFA-Verlag, Darmstadt, Germany.

Pfaffl, M. W. 2001. A new mathematical model for relative quantification in real-time RT-PCR. Nucleic Acids Res. 29:e45.

Reynolds, C. K., P. C. Aikman, B. Lupoli, D. J. Humphries, and D. E. Beever. 2003. Splanchnic metabolism of dairy cows during the transition from late gestation through early lactation. J. Dairy Sci. 86:1201-1217.
Rukkwamsuk, T., T. Wensing, and M. J. H. Geelen. 1999. Effect of fatty liver on hepatic gluconeogenesis in periparturient dairy cows. J. Dairy Sci. 82:500-505.

SAS Institute. 2009. SAS/STAT ${ }^{\circledR} 9.2$ User's Guide. 2nd ed. SAS Institute Inc., Cary, NC.

Schlegel, G., R. Ringseis, J. Keller, F. J. Schwarz, and K. Eder. 2012 Changes in the expression of hepatic genes involved in cholesterol homeostasis in dairy cows in the transition period and at different stages of lactation. J. Dairy Sci. 95:3826-3836.

Sejersen, H., M. T. Sørensen, T. Larsen, E. Bendixen, and K. L. Ingvartsen. 2012. Liver protein expression in dairy cows with high liver triglycerides in early lactation. J. Dairy Sci. 95:2409-2421.

van Dorland, H. A., S. Richter, I. Morel, M. G. Doherr, N. Castro, and R. M. Bruckmaier. 2009. Variation in hepatic regulation of metabolism during the dry period and in early lactation in dairy cows. J. Dairy Sci. 92:1924-1940.

Velez, J. C., and S. S. Donkin. 2005. Feed restriction induces pyruvate carboxylase but not phosphoenolpyruvate carboxykinase in dairy cows. J. Dairy Sci. 88:2938-2948.

Viturro, E., M. Koenning, A. Kroemer, G. Schlamberger, S. Wiedemann, M. Kaske, and H. H. D. Meyer. 2009. Cholesterol synthesis in the lactating cow: Induced expression of candidate genes. J. Steroid Biochem. Mol. Biol. 115:62-67.

Voet, D., and J. G. Voet. 1995. Biochemistry. 2nd ed. John Wiley and Sons, New York, NY.

Weber, C., C. Hametner, A. Tuchscherer, B. Losand, E. Kanitz, W. Otten, S. P. Singh, R. M. Bruckmaier, F. Becker, W. Kanitz, and H. M. Hammon. 2013. Variation in fat mobilization during early lactation differently affects feed intake, body condition, and lipid and glucose metabolism in high-yielding dairy cows. J. Dairy Sci. $96: 165-180$.

White, H. M., S. L. Koser, and S. S. Donkin. 2011. Characterization of bovine pyruvate carboxylase promoter 1 responsiveness to serum from control and feed-restricted cows. J. Anim. Sci. 89:1763-1768. 